\title{
Experimental Study on the Use of Pumice on the Rigid Pavement
}

\author{
Abdul Gaus ${ }^{\text {**, }}$ Imran ${ }^{\mathrm{b}}$, Chairul Anwar ${ }^{\mathrm{c}}$, Liska Novianti ${ }^{\mathrm{d}}$ \\ ${ }^{a}$ Department of Civil Engineering, Faculty of Engineering, Khairun University. Email: gaussmuhammad@gmail.com \\ bepartment of Civil Engineering, Faculty of Engineering, Khairun University. Email: imranimonamakuimo@outlook.com \\ 'Department of Civil Engineering, Faculty of Engineering, Khairun University. Email: chairul_anwar@gmail.com \\ ${ }^{\mathrm{d}}$ Department of Civil Engineering, Faculty of Engineering, Khairun University. Email: liskasan0211@ gmail.com
}

\begin{abstract}
The Pumice is a bright colored butian type, containing foam made from glass-walled bubbles and usually referred to as silicate volcanic glass granules. This pumice can be used as a substitute for normal sand as fine aggregate in a mixture of concrete mix. Based on the characteristic test examination, it can be seen that in testing the characteristics of pumice to the specifications of normal sand in specific gravity testing and weight testing of quicksand obtained results that are smaller than the specifications of normal sand and absorption tests obtained results greater than specifications on normal sand. The results of the normal sand compressive strength at BN is 250.95 $\mathrm{kg} / \mathrm{cm}^{2}$ while the results of the floating sand concrete compressive strength on BPA is $224,965 \mathrm{~kg} / \mathrm{cm}^{2}$. Based on the research, it can be concluded that with the same quality of concrete, the quality of K-250 is different in comparison to the compressive strength of concrete in normal sand and pumice concrete shows almost the same results. Therefore, a more in-depth research is needed regarding the use of pumice instead of normal sand in a mixture of concrete mix.
\end{abstract}

Keywords: Compressive strength; concrete; pumice; sand concrete

\section{Introduction}

The development of concrete is necessary to improve the field of development. The development of civil engineering is very rapid and driven by the development of concrete technology and the concrete products produced are very innovative. Concrete can be said to be the main ingredient of construction buildings in Indonesia.

Ternate City is one of the areas in North Maluku that has the availability of sand, but if it is used continuously, the amount of sand will be depleted, therefore it is necessary to have an innovation related to the use of sand. Ternate City is an area with growing and increasing population mobility which is growing quite rapidly. The development of residential areas in Ternate caused an increase in the need for sufficient facilities and infrastructure. Nowadays the use of lightweight concrete is a very good alternative because of high quality concrete that has been used as a basic material for thousands of years ago is used for application in building construction. Normal concrete density is very high, which is around $2400 \mathrm{~kg} / \mathrm{m}^{3}$ so that the dead load will be very large. To reduce the dead load of a concrete structure or reduce heat

\footnotetext{
${ }^{*}$ Corresponding author.

Civil Engineering Department, Khairun University,

Jl. Jusuf Abdulrahman Unkhair Gambesi

Ternate Selatan, Indonesia, 97718
}

transfer properties, it is necessary to use lightweight concrete using floating sand with a weight between 500$900 \mathrm{~kg} / \mathrm{m}^{3}$. Therefore, pumice is a material that is very suitable for use in lightweight concrete mixtures because it is able to absorb water on the surface and is very resistant to heat, then the shear behavior of the beam will be examined due to the use of pumice.

Natural resources are found in the Tidore Islands, one of which is the availability of pumice that can be used to make concrete. Based on the survey, it is necessary to innovate concrete mixes using quicksand which is then compared with the results of the concrete compressive strength in normal circulation. Therefore, it is necessary to have an in-depth study of the concrete press in the quicksand and the results of the compressive strength can be accounted for. Several research on lightweight concrete have been carried out based on literature studies on the number of writings and results that have been carried out based on laboratory tests and field testing.

Throughout the knowledge of the author, similar studies have never been conducted. I Made Alit Karyawan Salain conducted a study on compressive strength and modulus of lightweight concrete elasticity using pumice aggregate and flying ash as a substitute for most portland cement and superplasticizer [1]. This research was conducted to determine the mechanical behavior of 
Table 1. Various types of concrete and its characteristic

\begin{tabular}{|c|c|c|c|c|c|}
\hline \multirow{3}{*}{ No } & \multirow{3}{*}{ Type of lightweight concrete } & Specific gravity in & Compressive & Dry & Temperature \\
\hline & & the air & Strenght & shrinkage & Conductivity \\
\hline & & $\left(\mathrm{kg} / \mathrm{m}^{3}\right)$ & $\left(\mathrm{N} / \mathrm{mm}^{2}\right)$ & $(\%)$ & $\left(\mathrm{W} / \mathrm{M}^{0} \mathrm{C}\right)$ \\
\hline 1 & $\begin{array}{l}\text { hardened roasted ash flour } \\
\text { (Lytag) }\end{array}$ & $1360-1760$ & $14-42$ & $0.04-0.07$ & $0.32-0.91$ \\
\hline 2 & $\begin{array}{l}\text { Slate or clay developed } \\
(\text { Agli \& Leca) }\end{array}$ & $1360-1840$ & $14-42$ & $0.04-0.07$ & $0.24-0.91$ \\
\hline 3 & $\begin{array}{l}\text { Charcoal foam } \\
\text { (Foamed Slag) }\end{array}$ & $1680-2080$ & $10.5-42$ & $0.03-0.07$ & $0.24-0.93$ \\
\hline 4 & Pumice & $720-1440$ & $2-14$ & $0.04-0.08$ & $0.21-0.6$ \\
\hline 5 & Clinker (hardened granules) & $1040-960$ & $2-7$ & $0.04-0.18$ & $0.35-0.67$ \\
\hline 6 & $\begin{array}{l}\text { Stir in cement mixed with air } \\
\text { (aerated })\end{array}$ & $400-960$ & $1.4-4.9$ & $0.02-0.03$ & $0.10-0.22$ \\
\hline 7 & Solid concrete with gravel or & $2240-2480$ & $14-70$ & $0.03-0.05$ & $1.40-1.80$ \\
\hline
\end{tabular}

lightweight concrete beams including compressive strength and modulus of elasticity of lightweight concrete. Nenni Simamora dan Mukti Hamza Harahap studied the effect of styrofoam addition with toluene solvents against press strength and modulus of elasticity of lightweight concrete [2]. This study aims to determine the effect of adding Styrofoam with toluene solvents on compressive strength and modulus of elasticity of lightweight concrete. Ratna Widyawati investiagted uptake, penetration and permeability of lightweight concrete [3]. This research was conducted to find out how much the lightweight concrete porosity as one of the concrete durability benchmarks, in this study carried out absorption test, penetration, and permeability of lightweight concrete. The test results show that the absorption value, penetration and water permeability of lightweight concrete increases with the increase in the value of the cement water factor.

Moreover, Purnawan Gunawan, Slamet Prayitno, dan Aroma Isman Abdul Majid studied the effect of adding zinc fiber to lightweight concrete with foam technology against compressive strength, tensile strength [4]. This research produced lightweight fibrous foam concrete, meaning lightweight concrete (specific gravity <1900 $\mathrm{km} / \mathrm{m}^{3}$ ). Based on the results of lightweight concrete compressive strength, aluminum fiber foam can be categorized as structural concrete. Bambang Supriyadi studied the sliding behavior in the layan state and the limits of the longitudinal reinforced concrete beam [5]. This study utilizes concrete weight reduction by examining the shear behavior of the beam in the boundary conditions. Pratikto investigated the utilization of lightweight concrete superplasticizers aggregate plastic bottled waste type of poly ethylene terephthalate (PET) [6]. This study looks for the ratio of mixtures of cement, coarse, fine and water aggregate and admixture enhancer substances.

Yudi Risdiyanto researched on concrete compressive strength study with weight ratio for mass concrete production using crushed stone rough aggregate (case study on sabo dam development project) [7]. This study aims to study the concrete compressive strength of K250 with weight ratio (WR) and volume ratio (VR) using coarse aggregate Batu Merapi broke as a trial mix on the
Sabo dam development project. Murdock and Brook [8] wrote in concrete materials and practices titled book that it is necessary to aggregate combinations to obtain a lower specific gravity than normal concrete density. The type of the lightweinght and characteristic can be can be seen in Table 1.

\section{Experiment}

This test was carried out at the Laboratory of the structure and materials of the engineering faculty of the civil engineering study program at Khairun University. In general, the design of test objects in this study are as follows:

1. The cylinder size is $30 \mathrm{~cm}$ high with a diameter of 15 $\mathrm{cm}$.

2. Using ordinary sand fine aggregates as comparative sand or sand control

3. Using fine aggregate pumice

The tool used to test the compressive strength of the cylinder is the $2000 \mathrm{kN}$ Compression Machine. This test is based on standard specifications [9] by using the following formula:

$$
f^{\prime} c=\frac{P}{A}
$$

where :

$$
\begin{array}{ll}
f^{\prime} \mathrm{c} & =\text { compressive strength }\left(\mathrm{kg} / \mathrm{cm}^{2}\right) \\
\mathrm{P} & =\text { maximum load }(\mathrm{kg}) \\
\mathrm{A} & =\operatorname{area}\left(\mathrm{cm}^{2}\right)
\end{array}
$$

This test uses 2 (two) specimens of cylinders with different fine aggregates but uses the same coarse aggregate, with a height of $30 \mathrm{~cm}$ and a diameter of $15 \mathrm{~cm}$ shown in Fig. 1 and variations in test objects can be seen in Table 2.

Tabel 2. Variation of test objects

\begin{tabular}{cccc}
\hline Test objects & CWF & Area $\left(\mathbf{c m}^{2}\right)$ & $\begin{array}{c}\text { Number of } \\
\text { sampels }\end{array}$ \\
\hline BN & 0,35 & 176,625 & 1 \\
\hline BP & 0,35 & 176,625 & 1 \\
\hline
\end{tabular}




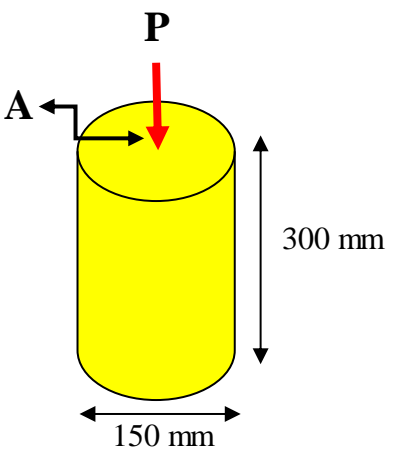

Figure 1. The Test specimens of concrete compressive strength

\section{Result and Discussion}

\subsection{Characteristic of fine agregate}

The results of the characteristics of the aggregate testing on normal sand and floating sand can be seen in Table 3. Normal sand which is used as a comparison for pumice is also tested for its characteristics so that it can be known the difference from the examination results on the two aggregates based on the specifications of the characteristic characteristics of fine aggregate according to SNI [10], to find out the testing specifications for fine aggregates. Figure 2 shows the image of fine aggregate gradation on normal sand and fine aggregate gradation on pumice.

Based on Table 3, it can be seen that the difference in the sludge level between normal sand and floating sand is $3.97 \%$, the difference in dry weight between normal sand and floating sand is 1.92 , the difference in dry weight of the saturated surface between normal sand and pumice is 2.07 , the difference in apparent density between normal sand and pumice is 1.93 , the difference in absorption between normal sand and pumice is $13.4 \%$, the difference in volume weight when the solid condition between normal sand and pumice is 1 , the difference in volume weight when the loose condition between normal sand and pumice is 0.94 and the difference in fine grained modulus between normal sand and pumice is 1.02.

Table 3. Characteristics of normal sand and pumice

\begin{tabular}{|c|c|c|c|}
\hline \multirow{2}{*}{ No } & \multirow{2}{*}{ Type of testing } & \multicolumn{2}{|c|}{ Result } \\
\hline & & Normal Sand & Pumice \\
\hline 1 & Sludge levels & $4.5 \%$ & $0.53 \%$ \\
\hline \multirow{5}{*}{2} & Specific gravity & & \\
\hline & Bulk specificgravity & 2.68 & 0.76 \\
\hline & Saturated surface dry & 2.7 & 0.63 \\
\hline & $\begin{array}{l}\text { Apparent specific } \\
\text { gravity }\end{array}$ & 2.75 & 0.82 \\
\hline & Absorption) & $1.5 \%$ & $14.98 \%$ \\
\hline \multirow{3}{*}{3} & Volume weight & & \\
\hline & Solid condition & 1.71 & 0.71 \\
\hline & Free condition & 1.6 & 0.66 \\
\hline 4 & Analysis of filter & $1.73 \%$ & $2.75 \%$ \\
\hline
\end{tabular}

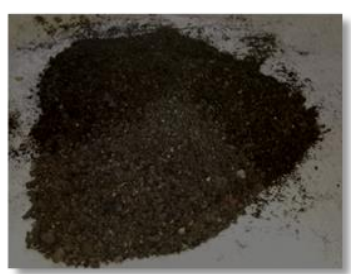

Normal Sand
Pumice

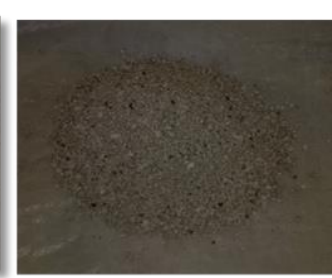

Figure 2. Gradation of fine agregate

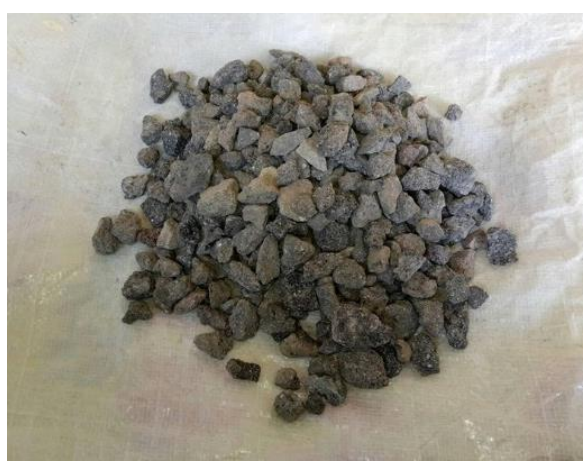

Figure 3. Gradation of coarse agregate

In Table 3, Volume weight on floating sand is lighter than normal sand specifications in SNI, in other words pumice is classified as lightweight concrete and can be used in a mixture of concrete mix. In the absorption test shown by Table 3, it is known that the absorption that occurs in floating sand is greatly increased and has a difference that is very far from absorption in normal sand, this is caused by the ability of pumice which has a very large water absorption capacity.

Based on Fig. 2, it can be seen that normal sand and quicksand in terms of texture are not much different. In terms of aggregate color, quicksand has a lighter color than the color of fine aggregate on normal sand.

This aggregate testing was carried out in the Structure and Material Laboratory of the Civil Engineering Department of the University of Khairun Ternate. In this study, there are two types of fine aggregate: normal sand fine aggregate originating from (quarry) Kalumata Village, Ternate. Other fine aggregates used in this study are quarry from Rumbune Village, Tidore. In this study, two types of fine aggregate were used because the comparison of characteristics between normal concrete and normal concrete would be compared to lightweight concrete. The results of this aggregate testing are based on SNI standards. The test results are presented in Table 3 and fine aggregate gradations are shown in Fig. 2.

This test is carried out to determine the characteristics of fine aggregates, namely normal sand is a fine aggregate originating from the Tubo Village, Ternate City and fine sand aggregate originating from the Kempland Tidore, which is then filtered to obtain sand gradation (pass No. 3 filter/8") and the next testing was carried out at the Engineering and Materials Laboratory of the Faculty of Engineering, Khairun Ternate University. This characteristic check on normal sand and floating sand is an examination of characteristics carried out with the same treatment in fine aggregates in general. In the normal sand characteristics testing, we discuss the standard parameters (specifications) that must be met by fine aggregate (normal sand) for the purpose of checking the results of 
testing of fine aggregates (normal sand and sand) carried out in the Laboratory. Testing Characteristics on Normal Sand (Kalumata quarry sand, Ternate is carried out as a comparison to the testing of characteristics that have been carried out on quicksand. As for the characteristics of normal sand can be seen in Table 3 .

\subsection{Testing concrete Compressive Strength}

According to Wang and Salmon [11] the compressive strength of concrete is the magnitude of the load per unit area, which causes the concrete test object to disintegrate when a certain compressive force is generated by the press machine. The compressive strength of concrete is of paramount importance in concrete quality compared to other properties. The compressive strength of concrete is determined by the arrangement of the ratio of cement, coarse and fine aggregate, water. Comparison of cement water, the higher the compressive strength. A certain amount of water is needed to provide chemical action in hardening the concrete, excess water increases the ability of the work but decreases strength.

For testing the compressive strength of concrete that was carried out in the Structure and Civil Engineering Laboratory of Khairun Ternate University. There are two kinds of samples used in this test, namely K250 concrete quality for normal concrete and K250 concrete quality for floating sand concrete, then the two samples are mixed design with the same FAS, namely FAS 0.35. In the composition composition table for concrete quality K250 for normal concrete samples can be seen in Table 4 .

Table 4 shows the results of comparison of cement water factors in normal concrete that is 0.35 with cement $627.62 \mathrm{~kg} / \mathrm{m}^{3}$, sand as much as $381.39 \mathrm{~kg} / \mathrm{m}^{3}$ with broken stones as much as $621.343 \mathrm{~kg} / \mathrm{m}^{3}$. The value obtained in Table 4 is the value obtained based on testing the characteristics of aggregation based on the results of the barchart aggregation between normal sand and coarse aggregate (split stone), while the results obtained from the barchart aggregation are the results obtained by using trial and error, as well as the barchart value obtained from the aggregation between quicksand and coarse aggregate. In floating sand concrete with the same water ratio of cement water factor is 0.35 with cement $585.71 \mathrm{~kg} / \mathrm{m}^{3}$, floating sand as much as $402.91 \mathrm{~kg} / \mathrm{m}^{3}$ with broken stones as much as $656.38 \mathrm{~kg} / \mathrm{m}^{3}$. Coarse aggregates used in normal concrete mixtures and floating sand concrete are the same coarse aggregates of the same quarry. The coarse aggregate gradations used in normal concrete and floating sand concrete are shown in Fig. 3, while the comparison composition of cement water in the concrete quality mixture K250 for floating sand concrete samples can be seen in Table 5.

Tabel 4. Cement water ratio of normal concrete

\begin{tabular}{ccc}
\hline $\begin{array}{c}\text { Concrete } \\
\text { material }\end{array}$ & $\begin{array}{c}\text { Weight } \\
\left.\text { (ton/m } \mathbf{m}^{\mathbf{3}}\right)\end{array}$ & $\begin{array}{c}\text { Ratio of } \\
\text { cement }\end{array}$ \\
\hline Cement & 0.627 & 1.00 \\
\hline Split & 0.381 & 0.61 \\
\hline $\begin{array}{c}\text { Natural } \\
\text { Stone }\end{array}$ & 0.621 & 0.99 \\
\hline Water & 0.219 & 0.35 \\
\hline
\end{tabular}

Table 5. Ratio of cement water at pumice concrete

\begin{tabular}{ccc}
\hline $\begin{array}{c}\text { Concrete } \\
\text { Material }\end{array}$ & $\begin{array}{c}\text { Weight } \\
\left(\text { ton/m } \mathbf{m}^{\mathbf{3}}\right)\end{array}$ & $\begin{array}{c}\text { Ratio of } \\
\text { cement }\end{array}$ \\
\hline Cement & 0.585 & 1.00 \\
\hline Pumice & 0.402 & 0.69 \\
\hline Split & 0.656 & 1.12 \\
\hline Water & 0.205 & 0.35 \\
\hline
\end{tabular}

When testing concrete compressive strength, the first thing to do is checking the tools and materials as follows: 1. Cylinder mold, $152 \mathrm{~mm}$ diameter, $305 \mathrm{~mm}$ height;

2. Compactor stick, diameter $16 \mathrm{~mm}$, length $600 \mathrm{~mm}$, with rounded ends, made of clean steel and rust free;

3. Stirrer or water-resistant concrete mixing tank;

4. Scales with an accuracy of $0.3 \%$ of sample weight;

5. Press machine, capacity as needed;

6. A set of capping tools;

7. Additional equipment: bucket, shovel, spoon, leveling spoon, and talam;

8. A set of slump check tools, This test is shown in Fig.4

9. A set of concrete weight inspection equipment.

After the testing tools and materials have been prepared, the next thing that needs to be done is to do a physical examination of the material that will be used as a mixture of concrete, namely: physical examination of coarse aggregates and fine aggregates, while physical inspection of these materials must meet the specification specifications aggregates based on the specifications of the Indonesian National Standard (SNI). After carrying out a physical examination of the material both on coarse aggregates and fine aggregates, then the next is to make a concrete composition composition planning, then the next step is the manufacture of test items, the following is the procedure for making test specimens on concrete:

- Fill the mold with a mixture of concrete in 3 layers, each layer is compacted with 25 times the puncture evenly. At the time of compaction of the first layer, the compacting stick may not hit the mold base, when compaction of the second layer and the three compacting sticks may enter approximately $25.4 \mathrm{~mm}$ into the layer below;

- After completing compaction, tap the side of the mold slowly until the puncture cavity is closed, flatten the

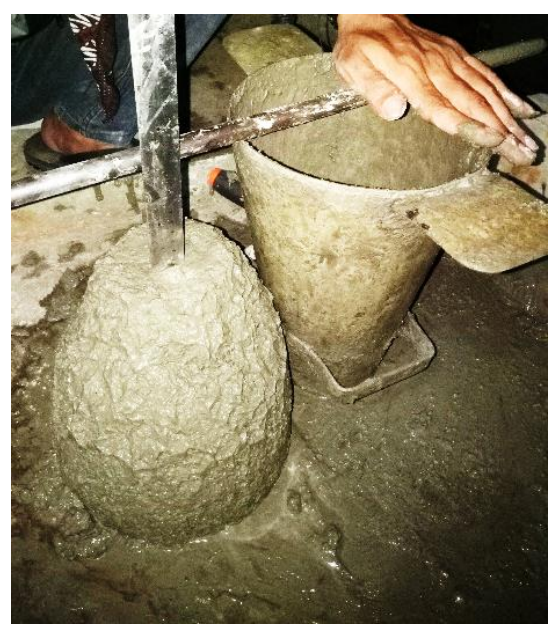

Figure 4. Concrete slump testing 
surface of the concrete and cover it immediately with a waterproof and rust resistant material, then leave the concrete in the mold for 24 hours and place it in a place free of vibration.

- After 24 hours, open the mold and remove the test object, to plan the concrete mixture, soak the specimen in the tank containing water at a temperature of $250 \mathrm{C}$ mentioned for curing, for the desired time, to control the concrete quality during concreting, ripening (curing) adjusted to requirements.

Then the next step is to test the compressive strength of the concrete, the following are the steps that must be followed in testing the compressive strength of the concrete:

1. Take a specimen that will determine its compressive strength from the soaking tub, then clean it from the dirt that is stuck with a damp cloth;

2. Determine the weight by means of weighing the specimen as shown in Fig. 5 and the size of the test object;

3. Capping the upper and lower surfaces of the specimen with sulfur mortar. This is done so that the surface of the test object becomes smooth and flat and facilitates the loading process on the test object until it becomes destroyed;

4. Place the test object on the machine press centricly;

5. Run the press machine with constant load increases ranging from 2 to $4 \mathrm{~kg} / \mathrm{cm}^{2}$ per second;

6. Perform the loading until the test is destroyed and record the maximum load that occurs during the examination of the test object.

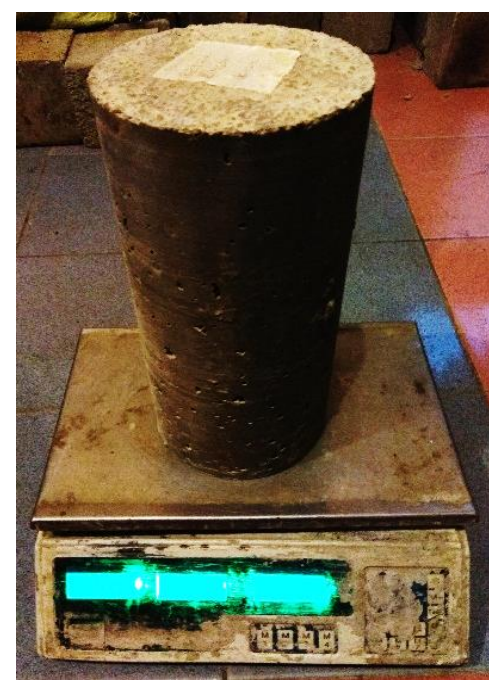

Figure 5. Concrete weight measurement

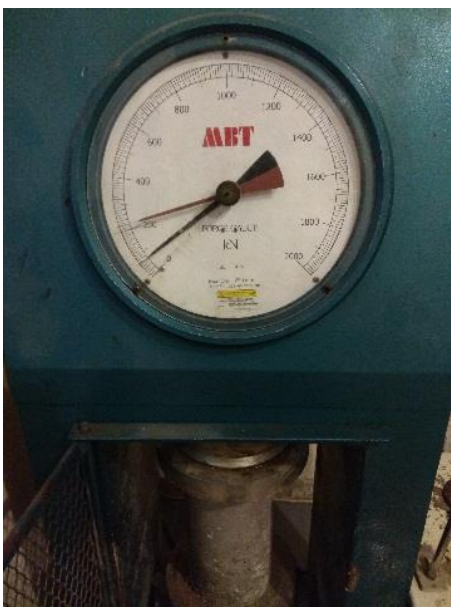

Figure 6. Compressive strength test

After the stage of making concrete specimens, the final step is the data analysis stage, which is analyzing the results of the compressive strength that has been obtained in the tests that have been carried out in the laboratory.

Testing of concrete compressive strength is carried out when the age of concrete has reached 28 days. Histograms test results of normal concrete compressive strength and quicksand concrete can be seen in Fig. 6 as follows:

Testing of the compressive strength of the cylinder uses two samples with different fine aggregates, namely concrete that uses normal sand and concrete that uses pumice. Testing of compressive strength in normal concrete and floating sand concrete was carried out using the same variation of Cement Water Factor (FAS), namely FAS 0.35. Based on the results of the compressive strength test results obtained compressive strength in normal concrete is $252.351 \mathrm{~kg} / \mathrm{cm}^{2}$ and the compressive strength test results on floating sand concrete is $224.281 \mathrm{~kg} / \mathrm{cm}^{2}$. The quality of concrete in this normal concrete mixture is the same concrete quality as the mixture with fine aggregates that use quicksand, namely the K-250 concrete quality.

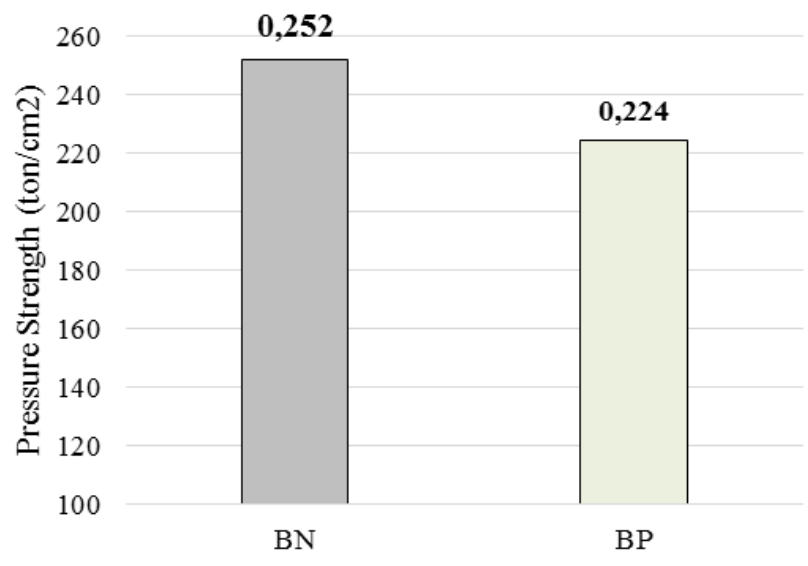

Figure 7. Histogram of testing compressive strength on concrete 


\section{Conclusion}

Based on the results of the study, it can be concluded as follows:

1. The test results on the compressive strength of concrete that is between the normal sand and floating sand has a compressive strength that is not much different, that is the results of the normal sand concrete compressive strength at $\mathrm{BN}$ is $252.351 \mathrm{~kg} / \mathrm{cm}^{2}$ and the results of the research $224.281 \mathrm{~kg} / \mathrm{cm}^{2}$ and the difference in compressive strength of both samples was 28.07 $\mathrm{kg} / \mathrm{cm}^{2}$.

2. The use of the pumice as a mixture of concrete does not affect the quality of compressive strength in concrete.

\section{Acknowledgement}

This research is funded by the Higher Education and is part of the essay by Liska Novianti.

\section{References}

[1] Salain, I., Compressive Strength and Modulus of Elasticity of Lightweight Concrete by Using Aggregates of Pumice and Fly Ash as a Substitute for Part of Portland Cement and Superplasticizer,
Proceeding of Seminar Nasional Teknik Sipil 1, 2015, 3-7. (in Bahasa)

[2] Simamora, N., Harahap, M., Effect of Addition of Stryfoam with Toluene Solvents on Compressive Strength and Modulus of Elasticity of Lightweight Concrete, Jurnal Einstein, 2015, 15-22. (in Bahasa)

[3] Widyawati, R., Absorption, Penetration and Permeability of Light Concrete, Proceeding of Seminar Nasional Sains dan Teknologi IV, Bandar Lampung, 2011, 29-33. (in Bahasa)

[4] Gunawan, P., Prayitno, S., Majid, A, I.A., The Effect of Zinc Fiber Addition on Lightweight Concrete with Foam Technology on Compressive Strength, Tensile Strength and Modulus of Elasticity, Konferensi Nasional Teknik Sipil, 2013. (in Bahasa)

[5] Supriyadi, B., et. al., Behavior of Sliding in the State of Service and Limits of Lengthy Perforated Concrete Beams, Jurnal Ilmiah Semesta Teknika, 2010, 145-154. (in Bahasa)

[6] Risdiyanto, Y., Study of Concrete Compressive Strength with a Weight Ratio for Mass Concrete Production using Coarse Aggregate of Broken Stone Merapi (Case Study on the Sabo Dam Construction Project), Civil Engineering, Universitas Negeri Yogyakarta, 2013. (in Bahasa)

[7] Pratikto, Utilization of Lightweight Concrete Superplasticizer Waste Plastic Bottle with aggregate Poly Ethylene Terephthalate (PET), Poli Teknologi Vol, 10 No. 1, 2011. (in Bahasa)

[8] Murdock, L.J., Brook, K.M., 1986, Concrete Materials and Practices, $4^{\text {th }}$ Edition, Erlangga, Jakarta, 1986. (in Bahasa)

[9] BSNI, Concrete Press Strength Testing Method (SNI 03-28472002), Jakarta, 2002. (in Bahasa)

[10]BSNI, Methods of Testing Fine and Coarse Aggregate Filters Analysis (SNI 03-1968-1990), Jakarta, 1990. (in Bahasa)

[11]Wang., Salmon., Press Strength Testing on Concrete, Jakarta, 1990 (in Bahasa) 